\title{
Correction to: Are You Really Happy? Children's Understanding of Real vs. Pretend Emotions
}

\author{
Francesc Sidera $^{1} \cdot$ Anna Amadó $^{1} \cdot$ Elisabet Serrat $^{1}$
}

Published online: 1 July 2019

(C) The Author(s) 2019

\section{Correction to: Curr Psychol (2013) 32:18-31 https://doi.org/10.1007/s12144-012-9159-9}

The article Are You Really Happy? Children's Understanding of Real vs. Pretend Emotions, written by Francesc Sidera, Anna Amadó and Elisabet Serrat, was originally published electronically on the publisher's internet portal (currently SpringerLink) on 29 December 2012 without open access. With the author(s)' decision to opt for Open Choice the copyright of the article changed on December 2012 to (C) The Author(s) 2019 and the article is forthwith distributed under the terms of the Creative Commons Attribution 4.0 International License (http:// creativecommons.org/licenses/by/4.0/), which permits use, duplication, adaptation, distribution and reproduction in any medium or format, as long as you give appropriate credit to the original author(s) and the source, provide a link to the Creative Commons license and indicate if changes were made.

The original article has been corrected.

Open Access This article is distributed under the terms of the Creative Commons Attribution 4.0 International License (http:// creativecommons.org/licenses/by/4.0/), which permits unrestricted use, distribution, and reproduction in any medium, provided you give appropriate credit to the original author(s) and the source, provide a link to the Creative Commons license, and indicate if changes were made.

Publisher's note Springer Nature remains neutral with regard to jurisdictional claims in published maps and institutional affiliations.

The online version of the original article can be found at https://doi.org/ 10.1007/s12144-012-9159-9

Francesc Sidera

francesc.sidera@udg.edu

Anna Amadó

anna.amado@udg.edu

Elisabet Serrat

elisabet.serrat@udg.edu

1 Department of Psychology, Facultat d'Educació i Psicologia,

University of Girona, Campus de Barri Vell, Plaça Sant Domènec, 9, 17071 Girona, Spain 